\title{
MANAJEMEN PENDIDIKAN KECAKAPAN HIDUP MELALUI PROGRAM KELAS MUSIK DI LEMBAGA KURSUS DAN PELATIHAN SYMPHONY MUSIC SCHOOL KOTA TASIKMALAYA
}

\author{
Nastiti Novitasari $^{1}$, Lulu Yuliani ${ }^{2}$ \\ ${ }^{1,2}$ Jurusan Pendidikan Masyarakat, FKIP, Universitas Siliwangi Tasikmalaya \\ nastiti@unsil.ac.id
}

\begin{abstract}
Abstrak
Pendidikan Kecakapan Hidup atau Life skills merupakan pendidikan yang dapat memberikan bekal keterampilan yang praktis, terpakai, terkait dengan kebutuhan pasar kerja, peluang usaha dan potensi ekonomi atau industri yang ada di masyakarat. Tujuan penelitian ini untuk mengetahui bagaimana manajemen pendidikan program kelas musik di lembaga kurus dan pelatihan Symphony Music School Kota Tasikmalaya. Penilitian ini menggunakan metode deskriptif dengan pendekatan kualitatif. Teknik pengumpulan data yang dilakukan pada penelitian ini yakni melalui wawancara dan observasi. Hasil penelitian menunjukkan bahwa manajemen pendidikan kecakapan hidup melalui program kelas musik di LKP Symphony Music School sesuai dengan teori manajemen pendidikan luar sekolah, yang dimulai dari tahap perencanaan, sampai dengan evaluasi. Saran yang dapat diberikan oleh peneliti yakni Sebaiknya, perlu dilakukan tracking lulusan, untuk memberikan motivasi dan memperluas pandangan karir dan pengembangan bakat kepada warga belajar. 2) Sebaiknya, perlu diadakan kunjungan/out class ke lembaga/institusi/kampus/sekolah musik untuk memberikan motivasi dan mempertahankan minat serta sharing ilmu untuk pengembangan program sesuai dengan perkembangan jaman dan kebutuhan pasar.
\end{abstract}

Kata kunci : Manajemen pendidikan, Lembaga Kursus Pelatihan, Pendidikan Kecakapan Hidup.

\section{Abstract}

Life skills education is an education that can provide practical skills, used, related to the needs of the job market, business opportunities and economic or industrial potential in the community. The purpose of this study was to find out how the management of music class programs education in skinny institutions and the training of Symphony Music School Tasikmalaya City. This research uses descriptive methods with a qualitative approach. The data collection techniques carried out in this study are through interviews and observations. The results showed that the management of life skills education through the music class program at LKP Symphony Music School is in accordance with the theory of management of education outside the school, which starts from the planning stage, up to the evaluation. Advice that can be given by researchers, namely, should be done tracking graduates, to provide motivation and expand the view of career and talent development to learning citizens. 2) Preferably, it is necessary to hold a visit / out class to institutions / institutions / campus / music schools to provide motivation and maintain interest and knowledge sharing for program development in accordance with the times and market needs.

Key Words: Educational management, Course and training institutions, Life Skills Education 


\section{PENDAHULUAN}

Belajar merupakan perubahan tingkah laku atau penampilan, dengan serangkaian kegiatan, misalnya dengan membaca, mengamati, mendengarkan, meniru, dan lain sebagainya. Belajar akan lebih baik, ketika subjek belajar mengalami atau melakukannya (Sardiman, 2018:20). Definisi belajar ini mengakomodasi semua tujuan belajar, dimulai dari tujuan mendasar yakni mengetahui fakta hingga tujuan dalam tingkat tertinggi yakni dapat memecahkan permasalahan (Problem solving)

Paradigma baru pendidikan mengisyaratkan bahwa tanggung jawab pendidikan tidak hanya diserahkan kepada Sekolah, namun dibutuhkan juga kerjasama dengan masyarakat. Dalam hal ini masyarakat turut serta bertanggung jawab atas terselenggaranya pendidikan. Dalam makna luas masyarakat dapat berpartisipasi untuk merancang dan menentukan jenis pendidikan yang dibutuhkan, karena pada era globalisasi ini masyarakat dituntut untuk dapat beradaptasi dan menyesuaikan diri diri dengan perkembangan zaman. Masyarakat tidak bisa hanya terpaku pada pendidikan yang kaku, yang kurang memberikan bekal keterampilan dan pengalaman.

Berdasarkan hal tersebut UNESCO telah merekomendasikan empat pilar pembelajaran, yakni program pembelajaran yang diberikan pada era globalisasi hendaknya mampu memberikan kesadaran kepada masyarakat sehingga mau dan mampu belajar (Learning know or learning to learn). Bahan Belajar yang dipilih hendaknya mampu memberikan suatu pekerjaan alternatif kepada peserta didiknya (Learning to do), dan mampu memberikan motivasi untuk hidup dalam era sekarang dan memiliki orientasi hidup di masa depan (learning to be). Pembelajaran tidak cukup diberikan kepada dirinya sendiri, tetapi juga keterampilan untuk hidup keterampilan untuk hidup bertetangga, bermasyarakat, berbangsa (Learning to live together). (Anwar, 2015:5)

Pada era globalisasi ini masyarakat juga dituntut untuk memiliki kecakapan hidup agar dapat mengembangkan kemampuan sesuai dengan minatnya. Pendidikan kecakapan hidup merupakan salah satu program pendidikan nonformal yang memiliki peran penting dalam rangka membekali warga belajar agar dapat hidup secara mandiri. Badan Kesehatan Dunia (WHO) mendefinisikan bahwa kecakapan hidup merupakan sebuah keterampilan yang memiliki kemampuan untuk beradaptasi dan berperilaku positif. Dengan demikian memungkinkan seseorang mampu menghadapi berbagai tuntutan dan tantangan dalam kehidupan secara lebih efektif (Pusat Kurikikulum Balitbang Depdiknas, 2004). Hal ini juga sejalan dengan pendapat (Anwar. 2015:20) Program pendidikan Life skills (Kecakapan Hidup) adalah pendidikan yang dapat memberikan bekal ketrampilan yang praktis, terpakai, terkait dengan kebutuhan pasar kerja , peluang usaha dan potensi ekonomi atau industri masyarakat.

Kecakapan hidup bisa dilatih, dan ditekuni. Hal ini bisa didapatkan pada kegiatan kursus dan pelatihan, Kursus adalah suatu kegiatan pendidikan yang berlanngsung dalam masyarakat yang dilakukan secara sengaja, terorganisasi, sistematik, untuk memberikan suatu mata pelajaran atau rangkaian pelajaran tertentu kepada orang dewasa atau remaja tertentu dalam waktu yang relatif singkat, agar mereka memperoleh pengetahuan, keterampilan dan sikap yang dapat dimanfaatkan untuk mengembangkan dirinya dan masayarakat (Ishak, 2012: 52).

Shympony Music School merupakan Lembaga Kursus dan pelatihan yang berada di Kota Tasikmalaya. Lembaga ini memfasilitasi masyarkat untuk mengembangkan bakat, minat serta seluruh potensi yang dimilikinya, khususnya di bidang seni musik. Tujuan dari program kursus yang ditawarkan oleh lembaga ini adalah untuk meningkatkan bakat dan keterampilan warga belajar dalam memainkan isntrumen musik serta memberikan bekal kecakapan hidup 
melalui bidang seni. LKP Shympony merupakan lembaga yang sudah terjamin kualitas lulusannya, LKP ini telah menjadi tempat uji kompetensi satu-satunya pada bidang musik di Kota Tasikmalaya. LKP Shimpony juga telah diakui dengan akreditasi B oleh BAN PNF. LKP Shympony Music School telah menghasilkan lulusan-lulusan yang berkompeten, dan juga mencetak para juara di bidang musik pada beberapa perlombaan. Oleh karena hal tersebut, peneliti ingin mengungkap bagaimana Manajemen pendidikan kecakapan hidup dalam program kursus kelas Musik di LKP Shymphony Music School Tasikmalaya.

\section{KAJIAN TEORI}

Manajemen diartikan sebagai suatu ilmu, kiat, dan profesi. Manajemen dikatakan sebagai ilmu karena dipandang sebagai suatu sistem pengetahuan untuk memahami mengapa dan bagaimana orang dapat bekerja sama. (Luther, dalam Budiwibowo 2018:1) Sedangkan, menurut (Follet dalam Budiwibowo 2018:1) manajemen dianggap sebagai kiat dikarenakan manajemen mencapai sasaran melalui cara-cara dengan mengatur orang lain dalam melaksanakan tugas. Manajemen juga dapat dipandang sebagai profesi, karena dilandasi oleh keahlian khusus untuk mencapai suatu prestasi dan dituntun oleh kode etik tertentu. Dalam konteks pendidikan manajemen merupakan suatu kegiatan memadu padankan sumber-sumber pendidikan agar terpusat dalam usaha mencapai tujuan pendidikan yang telah ditentukan sebelumnya dengan mengarahkan orang-orang untuk mengatur sarana, bahan, alat, dan biaya serta dengan menggunakan metode tertentu melakukan aktivitas masing-masing.

Menurut (Sudjana, 2000:23) terdapat fungsi pengelolaan program pendidikan yakni; 1) Perencanaan (Planning) merupakan proses sistematis melalui kegiatan penyususnan dan pengambil alihan keputusan tentang tindakan yang akan dilakukan dengan mempertimbangkan sumber-sumber yang ada baik SDM maupun NonSDM; 2) Pengorganisasian (Organizing) merupakan kegiatan memadukan sumber daya manusia dengan sumber daya non manusia yang diperlukan untuk menjalankan rencana yang telah disusun dan ditetapkan sebelumnya; 3) Penggerakan (Motivating) merupakan upaya pimpinan atau pengelola untuk memotivasi bawahan atau staf dengan membangkitkan semangat atau dorongan yang ada di dalam diri mereka agar mampu melakukan kegiatan yang direncanakan untuk mencapai tujuan; 4) Pembinaan (Conforming) merupakan rangkaian upaya pengendalian profesional terhadap semua unsur organisasi, sehingga berfungsi sebagai mana mestinya dalam rangka pencapaian tujuan yang ditetapkan 5) Penilaian (evaluating) merupakan kegiatan sistematis untuk mengumpulkan, menganalisis dan menyajikan data atau informasi guna dijadikan masukan dalam pengambilan keputusan; 6) Pengembangan (Developing) upaya menindaklanjuti program ke tingkat program yang lebih baik lebih luas dan lebih kompleks.

Pendidikan Kecakapan Hidup atau Life skills merupakan pendidikan yang dapat memberikan bekal keterampilan yang praktis, terpakai, terkait dengan kebutuhan pasar kerja, peluang usaha dan potensi ekonomi atau industri yang ada di masyakarat (Anwar, 2015:20). Kursus dan pelatihan merupakan bentuk pendidikan berkelanjutan agar kemampuan yang dimiliki peserta didik dapat berkembang dan lebih menekankan pada penguasaan keterampilan, standar kompetensi, sikap kewirausahaan serta kepribadian profesional (Undang-Undang Sistem Pendidikan Nasional No. 20 tahun 2003 Bab VI Pasal 26 ayat 5). Satuan pendidikan non formal yang dapat menyelenggarakan kursus dan pelatihan adalah: 1) Lembaga Kursus dan Pelatihan (LKP). 2) Pusat Kegiatan Belajar Masyarakat (PKBM). 3) Sanggar Kegiatan Belajar (SKB), dan lembaga lain yang sejenis. (Konsep dasar pendidikan nonformal PKBM dan LKP BAN PT PAUDPNF). 


\section{METODE PENELITIAN}

Metode yang dilakukan oleh peneliti untuk mendeskripsikan dan mendapatkan pemahaman tentang pengelolaan program pendidikan kecakapan hidup pada kursus musik ini adalah metode deskriptif dengan pendekatan kualitatif. Pendekatan kualitatif merupakan pendekatan yang digunakan untuk mengeksplorasi dan memahami makna yang diperoleh dari sejumlah individu atau sekelompok orang yang dianggap berasal dari masalah sosial (Creswell, 2010, hlm. 4) Subjek dalam penelitian ini yakni pihak pengelola serta tutor yang ada di LKP Shymphony Music School dengan jumlah 9 orang. Pengambilan sampel dilakukan dengan teknik puposive sampling yaitu teknik untuk menentukan sampel penelitian dengan beberapa pertimbangan tertentu yang bertujuan agar data yang diperoleh nantinya bisa lebih representatif (Sugiyono 2010), sampel yang diambil dalam penelitian ini ada 8 orang, terdiri dari 2 pengelola dan 6 orang tutor. Teknik pengumpulan data dilakukan dengan beberapa cara, yakni melalui kegiatan wawancara dan observasi.

\section{HASIL DAN PEMBAHASAN}

LKP Shymphony Music School merupakan Lembaga Kursus Pelatihan yang berada di Jalan HZ. Mustofa Ruko Permata Raya Kompleks Permata Regency No. 33 Kota Tasikmalaya. LKP ini didirkan oleh Bapak Kepler Sianturi, M.A. Seorang praktisi pada bidang musik yang mempunyai keinginan untuk mencetak seniman-seniman musik berbakat di Kota Tasikmalaya. LKP ini diselenggarakan untuk mengembangkan bakat, minat serta seluruh potensi yang dimiliki masyarakat, khususnya di bidang seni musik. Penyelenggaraan Kursus pada LKP ini dilaksanakan setiap Hari Senin-Sabtu pukul 11.00-18.00 WIB selama 60 menit setiap pertemuan. Terdapat beberapa kelas khusus yakni, kelas Piano, Keyboard, Biola Klasik/Pop, Gitar Klasik/Pop/Kontemporer, Drum, Vokal, saxophone, Perkusi, Paduan suara, Kursus Musik daerah. Warga belajar pada LKP ini sangatlah beragam, mulai dari pelajar hingga mahasiswa. Mayoritas warga belajar ada pada usia 10-15 tahun. Tenaga Pengajar pada LKP Shimphony terdiri dari akademisi dan praktisi sesuai dengan bidang masing-masing. LKP Shymphony mengutamakan kualitas SDM nya dengan memberikan kesempatan peningkatan kompetensi Tenaga Pengajar/tutor. Sarana dan prasarana yang dimiliki juga sangat lengkap, terdiri dari ruang kelas sejumlah 10 kelas yang terbagi pada 4 lantai, ruang perpustakaan, ruang tunggu dan musholla. Sesuai dengan harapan Pendiri Lembaga, agar pendidikan nasional melalui musik daerah ataupun komtemporer mampu memberikan kontribusi terhadap penyelesaian berbagai masalah yang dihadapi bangsa Indonesia masa kini dan dimasa mendatang. Terutama tentang penigkatan kecakapan hidup warga belajarnya.

\section{Manajemen program Pendidikan kecakapan hidup melalui program kelas musik pada LKP Shymphony Music School}

Hasil penelitian yang diperoleh menunjukkan bahwa Manajemen Program Pendidikan Kecakapan Hidup yang ada pada LKP Shympony Music School dilandaskan pada lima fungsi pengelolaan atau manajemen, Yakni : Perencanaan, Pengorganisasian, Penggerakan, Pembinaan, dan Penilaian. (Sudjana, 2000:19)

\section{Perencanaan}

Pada tahap perencanaan, terdapat dua tujuan program yang ditetapkan LKP Shimphony Music School, yakni perencanaan program jangka pendek dan panjang. Pada program jangka pendek, pertunjukan "home concert" dijadikan alat pengukur keberhasilan warga belajar. Home concert adalah salah satu evaluasi yang diadakan di akhir program kursus. Untuk 
program jangka panjang LKP mengadakan bimbingan lanjutan bagi warga belajar yang akan melanjutkan pendidikan tinggi pada bidang seni musik.

Identifikasi kebutuhan belajar calon warga belajar dimulai dengan pengisian formulir pendaftaran, dilanjutkan proses wawancara, untuk mengetahui tingkat pengalaman dan keahlian yang dimiliki untuk dilakukan pengelompokan kelas sesuai grade. Hal ini sesuai dengan pendapat Joko Sutarto (2013, hlm. 21-22) dalam bukunya yang berjudul Manajemen Pelatihan, menyebutkan bahwa tujuan dari adanya rekruitmen peserta pelatihan adalah mendapatkan calon peserta pelatihan yang tepat sesuai dengan program pelatihan yang dirancang. Setelah proses wawancara dan pembagian kelas, calon warga belajar diberikan kesempatan untuk melakukan pembayaran, selanjutnya dibagikan jadwal dan perlengkapan kursus seperti (tas, majalah musik) LKP Shimpony memiliki strategi khusus untuk menarik minat masyarakat untuk bergabung pada kegiatan kursus, beberapa diantaranya adalah dengan menginfokan di media massa, facebook, Instagram serta media online lainnya, mengadakan konser di berbagai daerah dan pada event-event khusus untuk menunjukkan eksistensi di kalangan masyarakat sehingga dapat membuat masyarakat tertarik untuk mengikuti kegiatan kursus, selain itu warga belajar pada LKP Shimpony juga sering mengikuti perlombaanperlombaan, baik tingkat daerah maupun nasional.

Tutor/pengajar pada LKP Shimpony juga memiliki kualifikasi khusus, yakni yang memiliki keahlian di bidangnya dan tersertifikasi, serta harus memiliki beberapa kompetensi yaitu: kompetensi kepribadian, kompetensi professional, dan kompetensi sosial. Hal ini sesuai dengan Rifa'i (2009:8) dalam bukunya yang berjudul Desain Pembelajaran Orang Dewasa, bahwa tenaga pendidik yang profesional adalah yang memiliki kompetensi dengan kemampuan yang diandalkan, berdaya guna, dan berhasil guna, di dalam melayani dan membantu partisipan di dalam proses pembelajaran. Kurikulum yang digunakan saat pembelajaran adalah kurikulum SKKNI serta kurikulum khusus yang dirancang dari hasil diskusi dan kesepatakan bersama pemilik serta tutor yang ada.

\section{Pengorganisasian}

Struktur organisasi disusun sesuai dengan keahlian pada masing-masing bidang Berikut susunan organisasi yang ada pada LKP Shimpony Music School : 1) Ketua : Kepler Sianturi, M.A., 2) Sekretaris: Egi Sugihartono, S.IP., 3) Bendahara: Eva Revina, ,S.Sos., 4) Administrasi kesekretariatan : Elia Sundari., 5) Administrasi keungan: Putri., 6) Kepala UPT Lab : Ali Hermati Ulum. Serta pada tutor sesuai dengan bidang dan kemampuannya. Selain itu menjaga hubungan antarkelompok dengan membangun komitmen bersama dan menciptakan rasa saling memiliki menjadi kekuatan utama agar terjalinnya suasana yang harmonis.

\section{Penggerakan}

Penggerakan atau pelaksanakan dilakukan dengan cara menyesuaikan materi dengan tingkatan masing-masing kelas. Menurut hasil observasi yang telah dilakukan, tutor memberikan materi pembelajaran menggunakan beberapa metode, yakni; ceramah dan praktik dengan masing-masing prosentase $20 \%$ dan $80 \%$. Stimulus yang diberikan kepada warga belajar pada dasarnya sama, yakni meningkatkan pemahaman, meningkatkan keahlian serta memberikan motivasi agar warga belajar memiliki semangat untuk rutin berlatih, baik dengan tutor maupun secara mandiri. Penggerakan juga dilakukan terhadap tutor, dengan mengadakan rapat koordinasi secara rutin, membahas permasalahan yang ada serta solusinya. Serta merancang kegiatan-kegiatan yang aka diadakan di LKP Shimpony Music School. 


\section{Pembinaan}

Dalam tahap pembinaan, terdapat kegiatan pengawasan yang dilakukan langsung oleh Dinas Pendidikan/Penilik yang mengawasi program di LKP Shimpony Music School, selain itu juga dilaksanakan pengawasan dan pembinaan langsung oleh tutor terhadap perkembangan warga belajar dalam proses pembelajaran. Tutor dibina langsung oleh pemilik LKP untuk dapat menyesuaikan pembelajaran dengan tujuan kursus. Hal ini sesuai dengan Sudjana (2000:224) bahwa pembinaan meliputi dua sub-fungsi yaitu (controlling) dan (supervising). Kedua subfungsi ini memiliki kaitan yang sangat erat antara yang satu dengan yang lainnya, dan keduanya saling mengisi atau saling melengkapi. Dengan adanya pengawasan maka penyelenggaraan program akan terkontrol, sesuai/cocok, aman, terukur, seimbang, dan menumbuhkan motivasi dan semangat untuk para pelaksana program. Tutor juga diberikan kesempatan untuk mengembangkan kemampuannya, dengan mengikuti berbagai pelatihan, seminar dan ujian kompetensi yang diadakan khusus tiap tahunnya.

\section{Penilaian}

Pada tahap penilaian SKL digunakan sebagai patokan lulus tidaknya warga belajar pada program tersebut. Penilaian dilakukan dengan dua tahap yakni melalui ujian teori dan praktik, yang pada masing-masing tahap mempunyai SKL tertentu untuk menentukan kelulusan. Ujian praktik dilakukan dengan melaksanakan Home Concert, yakni pertanggung jawaban yang dilakukan oleh warga belajar selama melakukan kursus pada LKP Shimpony, pada kegiatan ini warga belajar menunjukkan hasil belajarnya dengan memainkan alat musik sesuai instrumen yang dipelajari saat kursus.

Berdasarkan penelitian yang dilakukan, manajemen atau pengelolaan program merupakan hal utama yang harus disusun secara sistematik, dirancang sedemikian rupa sehingga pelaksanaan program sesuai dengan tujuan program. Manajemen pendidikan kecakapan hidup yang dilaksanakan pada LKP Shimpony Music School sudah sesuai dengan teori pengelolaan program pendidikan, dimana terdapat kegiatan perencanaan hingga evaluasi yang dilakukan dalam pelaksanaannya. Terbukti dengan manajemen yang matang, dan terinci program kursus musik ini telah menghasilkan warga belajar yang kompeten dan ahli di bidangnya, beberapa kegiatan dan penghargaan telah berhasil diraih oleh LKP Shimpony Music School, diantaranya ; 1) Juara II yang diberikan oleh Gubernur Jawa Barat dalam Festival Vocal Group se-Jawa Barat, di Bandung tahun 2005., 2) Menjadi salah satu perwakilan dari Tasikmalaya dalam acara Concert Tour di New York Amerika Serikat., 3) Menjadi pengisi acara konser "Gelaran Seni Budaya" bersama kementerian Pariwisata dan Ekonomi Kreatif RI tahun 2014 di Graha Asia Plaza, 4) Juara 2 Lomba V-Factor tahun 2020, dan lain sebagainya.

\section{SIMPULAN DAN SARAN}

Berdasarkan hasil penelitian diperoleh kesimpulan, bahwa manajemen pendidikan kecakapan hidup melalui program kelas musik di lembaga kursus dan pelatihan Shimpony Music School dimulai dari tahap 1) perencanaan, mempersiapkan warga belajar, tutor dan tujuan program. 2) Pengorganisasian, sesuai dengan bidang dan kemampuan masing-masing., 3) Penggerakan, berupa metode dan koordinasi bersama pengelola dan tutor. 4) Pembinaan, dilakukan dan diawasi langsung oleh Dinas Pendidikan, serta pengelola. Hingga tahap 5) Penilaian, disesuaikan dengan SKL yang berlaku. Tahapan-tahapan manajemen telah dijalankan dengan baik dan sesuai dengan dasar peraturan yang berlaku. 
Saran yang dapat diungkapkan peneliti dari penelitian ini yaitu : 1) Sebaiknya, perlu dilakukan tracking lulusan, untuk memberikan motivasi dan memperluas pandangan karir dan pengembangan bakat kepada warga belajar. 2) Sebaiknya, perlu diadakan kunjungan/out class ke lembaga/institusi/kampus/sekolah musik untuk memberikan motivasi dan mempertahankan minat serta sharing ilmu untuk pengembangan program sesuai dengan perkembangan jaman dan kebutuhan pasar.

\section{DAFTAR PUSTAKA}

Abdulhak, Ishak. 2012. Penelitian Tindakan dalam pendidikan Nonformal. Jakarta: PT Rajagrafibdo Persada.

Anwar. 2015. Pendidikan Kecakapan Hidup (Life Skills Education). Bandung: Alfabeta

Budiwibowo, Sartijo, Sudarmiani. 2018. Manajemen Pendidikan. Yogyakarta:

Penerbit ANDI

Cresswell, J W. 2014. Research Design Pendekatan Kualitatif, Kuantitatif, dan Mixed. Yogyakarta : Pustaka Belajar.

Pusat Kurikikulum Balitbang Depdiknas. 2004.

Sardiman. 2018. Interaksi dan Motivasi Belajar-Mengajar. Jakarta: Raja Grafindo Persada.

Sudjana, D, 2000. Manajemen Program Pendidikan Luar Sekolah. Bandung: Falah Production. Sutarto, Joko. 2013. Manajemen Pelatihan. Yogyakarta: Penerbit Deepublish.

Undang-undang Nomor 20 Tahun 2003 